\title{
Distribution of Hepatitis C Virus Genotypes in Patients Diagnosed with Hepatitis C in Our Hospital: 2015-2018
}

\author{
Hastanemizde Hepatit C Tanısı Alan Hastalarda Hepatit C Virüs Genotiplerinin Dağılımı: \\ 2015-2018
}

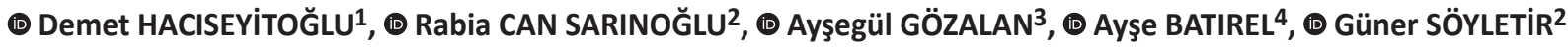 \\ ${ }^{1}$ Kartal Dr. Lütfi Kırdar Training and Research Hospital, Laboratory of Clinical Microbiology, Istanbul, Turkey \\ 2 Marmara University Faculty of Medicine, Department of Medical Microbiology, istanbul, Turkey \\ ${ }^{3}$ Alanya Alaaddin Keykubat University Faculty of Medicine, Department of Medical Microbiology, Antalya, Turkey \\ ${ }^{4}$ Kartal Dr. Lütfi Kırdar Training and Research Hospital, Clinic of Infectious Diseases and Clinical Microbiology, Istanbul, Turkey
}

\section{Abstract}

Introduction: This study aimed to investigate the distribution of hepatitis C virus (HCV) genotype and its variability in certain sociodemographics in patients with chronic hepatitis.

Materials and Methods: Anti-HCV was performed by chemiluminescent micro-particle immune assay (Abbott Architect i2000SR, Germany), and HCV-RNA viral load detection was applied with real-time reverse transcriptase polymerase chain reaction (RT-PCR) in the system

(Cobas AmpliPrep-Cobas TaqMan, Roche, Germany). Genotype detection was performed with RT-PCR upon with RT-PCR method in the system of Abbott RT-HCV Genotype 2 (Abbott Laboratories, USA) and with Bosphore-HCV Genotyping KitV3 in the Montania 4896 device (Anatolia Diagnostics and Biotechnology Products, Turkey). Frequency and percentage dispersions of all data obtained from patient files and laboratory information system were evaluated through the Statistical Package for the Social Sciences statistics software program.

Results: HCV-RNA was positive in 628 of 2,381 patients with anti-HCV positivity (26.4\%), and genotypes of 319 of which were evaluated. Mean age of 319 patients was 51.6 (standard deviation: 16.1). The most frequent genotypes were 1b (61\%), 3 (19\%), and 1a (10\%). Incidences of genotype $1 \mathrm{~b}$ among all genotypes between the dates of 2015-2018, were found $34.7 \%, 29 \%, 15.5 \%$ and $20.7 \%$ respectively ( $p=0.001$ ). Contagion sources were medical interventions, and $1 \mathrm{~b}$ was the most frequent genotype. Genotype 3 was most common in patients with intravenous drug addiction. A total of 168 of 238 patients who were Turkish citizens were detected to have genotype 1b, whereas 28 of them had genotype 3 and 25 had genotype 1a. Seventy-eight (24.7\%) of the 316 patients, whose genotypes were tested, were foreigners coming mostly from Georgia, Turkmenstan, and Syria respectively. The most frequent genotype of Georgian and Turkmenistanian was $1 \mathrm{~b}$ and Syrian was both $1 \mathrm{a}$ and 4.

Conclusion: This study shows the most frequent genotype to be $1 \mathrm{~b}$ and its prevalence is statistically decreased over the years, whereae other genotypes $(1 \mathrm{a}, 3,4,3 \mathrm{a}, 1 \mathrm{a} / 3,1 \mathrm{~b} / 3, \mathrm{c}-\mathrm{k}, 2 / 3,1 / 4,3 / 4$, and 5$)$ increased.

Keywords: Hepatitis $\mathrm{C}$ virus, epidemiology, genotype, intravenous drug addiction

\section{Öz}

Giriş: Hepatit C virüs (HCV) genotip tayini; tedavi protokolüne karar verilmesi ve tedaviye yanıtın izlenmesinde önemlidir. Bu çalışmada hastanemize başvuran ve kronik hepatit $C$ tanısı alan hastaların HCV genotip dağılımı ve dağılımın bazı sosyo-demografik özelliklere göre değişiminin araştırılması amaçlanmıştır.

Gereç ve Yöntem: Ocak 2015-Aralık 2018 yıllarında hastanemize başvuran anti-HCV pozitif hastalar retrospektif olarak incelendi. Anti-HCV kemiluminesan mikropartikül immünoassay yöntemiyle (Abbott Architect i2000SR, Almanya) ve HCV-RNA viral yük tayini tam otomatize gerçekzamanlı ters transkriptaz polimeraz zincir reaksiyonu (RT-PCR) yöntemiyle (Cobas AmpliPrep-Cobas Taqman, Roche, Almanya) sisteminde çalışıldı.

Cite this article as: Haciseyitoğlu D, Can Sarınoğlu R, Gözalan A, Batırel A, Söyletir G. Distribution of Hepatitis C Virus Genotypes in Patients Diagnosed with Hepatitis C in Our Hospital: 2015-2018. Mediterr J Infect Microb Antimicrob. 2021;10:7.

Address for Correspondence/Yazışma Adresi: Demet Hacıseyitoğlu MD, Kartal Dr. Lütfi Kırdar Training and Research Hospital, Laboratory of Clinical Microbiology; Marmara University Faculty of Medicine, Department of Medical Microbiology, İstanbul, Turkey

Phone: +90 2163520083 E-mail: demet634@gmail.com ORCID ID: orcid.org/0000-0001-7404-8347

Received/Geliş Tarihi: 03.11.2020 Accepted/Kabul Tarihi: 09.02.2021

oCopyright 2021 by the Infectious Diseases and Clinical Microbiology Specialty Society of Turkey Mediterranean Journal of Infection, Microbes and Antimicrobials published by Galenos Yayınevi.
Presented in: The article was presented at the $5^{\text {th }}$ National Clinical Microbiology Congress (October 28 to November 1, 2019, İzmir, Turkey) as a poster presentation.

Published: 10 February 2021 


\section{Öz}

Genotip tayini gerçek zamanlı PCR yöntemi ile Abbott RT-HCV Genotip 2 sisteminde (Abbott Laboratories, ABD) ve Bosphore HCV Genotyping Kiti V3 ile Montania 4896 cihazında (Anatolia Tanı ve Biyoteknoloji ürünleri, Türkiye) çalışıldı. Laboratuvar informasyon sistemi ve hasta dosyalarından elde edilen tüm verilerin frekans ve yüzde dağılımları Statistical Package for the Social Sciences istatistik programı ile değerlendirildi.

Bulgular: Anti-HCV pozitif 2.381 hastanın 628 'inde $(\% 26,4)$ HCV-RNA pozitifti ve bunların 319'unun genotipi değerlendirildi. Üç yüz on dokuz hastanın yaş ortalaması 51,6 (standart deviasyon: 16,1) olarak hesaplandı. En sık saptanan genotipler sırası ile; 1b (\%61), 3 (\%19) ve 1a (\%10) idi. Tüm genotiplerin içerisinde genotip $1 b$ görülme oranı 2015-2018 yıllarında sırasıyla; \%34,7, \%29, \%15,5, \%20,7) bulundu ( $p=0,001$ ). Türkiye Cumhuriyeti (T.C.) vatandaşı olan 238 hastanın 168'inde genotip 1b, 28'inde genotip 3 ve 25'inde genotip 1a saptandı. Olası bulaş yolu sorulan 80 T.C. vatandaşı hastaların çoğunda tıbbi bir müdahale vardı ve bu kişilerde de en sık görülen genotipin, 1b olduğu bulundu. İntravenöz ilaç bağımlılı̆ı olan 11 hastada (\%14) en sık genotip 3 tespit edildi. Genotipleri değerlendirilen 316 hastanın 78'i (\%24,7) yabancı uyruklu olup ilk üç sırayı Gürcistan, Türkmenistan ve Suriye almaktaydı. Gürcistan ve Türkmenistan'da en sık genotip 1b (sırasıyla \%48 ve \%60), Suriye'de ise eşit oranda genotip 1a ve 4 (\%42) görülmekteydi.

Sonuç: Bu çalışmada en sık saptanan genotipin $1 b$ olduğu, yıllar içinde 1b oranın istatistiksel olarak anlamlı şekilde düştüğü ve diğer genotiplerden $1 \mathrm{a}, 3,4,3 \mathrm{a}, 1 \mathrm{a} / 3,1 \mathrm{~b} / 3, \mathrm{c}-\mathrm{k}, 2 / 3,1 / 4,3 / 4$ 'ün oranlarının arttığı gösterilmiştir.

Anahtar Kelimeler: Hepatit C virüs, epidemiyoloji, genotip, intravenöz ilaç bağımlıı̆̆

\section{Introduction}

Chronic hepatitis $C$ is a liver infection caused by bloodborne transmission of hepatitis C virus (HCV). Most people are infected by sharing needles or other materials used in injection of drugs, and $70 \%(55-80 \%)$ of these people developed long-term chronic infection $^{[1]}$.

$\mathrm{HCV}$ has a single-stranded RNA genome with positive polarity, which is responsible for genetic diversity. The fact that the RNA-dependent RNA polymerase enzyme of the virus does not have backtracking (error correction) capability leads to mutations in glycoprotein and other genes, and consequently genetic diversity ${ }^{[2,3]}$. In terms of genetic diversity, at least seven genotypes and 67 subtypes have been demonstrated ${ }^{[4]}$. This genetic diversity, caused by three $\mathrm{N}$-terminal HCV proteins $\left(\mathrm{C}_{1} \mathrm{E} 1\right.$, and $\mathrm{E} 2 / \mathrm{NS} 2)$ and four C-terminal proteins (NS2, NS3, NS4, and NS5) involved in viral replication and an "Open reading frame" with different number of nucleotides in each genotype enabling the virus to escape from immune response, affecting the course and treatment of disease ${ }^{[3]}$. Viral load, alcohol consumption, and duration of exposure to HCV infection also play a role in the progression of liver damage ${ }^{[5]}$. In patients infected with genotype $1 b$, the severity of liver disease is higher compared to other genotypes, and the disease has a more aggressive course ${ }^{[3]}$. Hepatocellular carcinoma due to HCV most often develops with genotype $1 \mathrm{~b}$. Best long-term remission rates after treatment with a 48-week therapy with interferon and ribavirin are obtained in patients infected with genotype $1^{[6]}$.

Treatment objective for patients without cirrhosis is to decrease HCV-RNA below detectable limit in the $12^{\text {th }}$ and $24^{\text {th }}$ weeks after treatment $(<15 \mathrm{IU} / \mathrm{ml})$. Different genotypes may respond differently to drugs, thus, determining the quantity of HCV-RNA (in IU/ml) at the beginning of treatment with a sensitive method, deciding on drugs to be used in treatment, and identifying the genotype recommended ${ }^{[7]}$.

$\mathrm{HCV}$ genotyping is important in terms of determining treatment protocol and monitoring response, thus, this study aimed to evaluate the genotype distribution in patients admitted to our hospital between 2015 and 2018 and diagnosed with chronic hepatitis $\mathrm{C}$.

\section{Materials and Methods}

Data of 2,381 patients who applied to the Infectious Diseases Outpatient Clinic of Kartal Dr. Lütfi Kırdar Training and Research Hospital in İstanbul between January 1, 2015 and December 31, 2018, and whose anti-HCV antibody titers were positive, were obtained from the hospital automation system. Among these patients, 319 patients who were diagnosed with hepatitis C and whose HCV-RNA viral load and genotype were determined were included in the study. HCV-RNA levels and genotypes were evaluated from initial blood samples of patients. Possible transmission routes for $\mathrm{HCV}$ were evaluated by examining patient records.

\section{Detection of Anti-HCV}

Anti-HCV detection in serum samples taken from patients was performed by chemiluminescent micro-particle immune assay method (Architect Anti-HCV, Abbott Laboratories, USA), and the index value of results (cut-off index) was recorded. Samples with anti-HCV reactivity were analyzed two more times with the same method, and cases with reactivity in two out of three analyses were recorded as recurrent reactivity.

\section{Determination of HCV-RNA Viral Load}

The presence of HCV-RNA in plasma samples was studied with nucleic acid extraction and quantitative real-time everse transcriptase polymerase chain reaction (RT-PCR) method (Cobas 
AmpliPrep-Cobas TaqMan HCV Test, v2.0, Roche Diagnostics Germany). The lower limit for detecting HCV-RNA was $15 \mathrm{IU} / \mathrm{ml} . "$

\section{Testing for HCV Genotype Determination}

Until October 2017, genotyping was performed in an Abbott RTHCV Genotype 2 system (Abbott Laboratories, USA) by RT-PCR method, and samples were scanned for genotypes $1,2,3,4,5$, $6,1 \mathrm{a}$, and $1 \mathrm{~b}$. In this method, the HCV-RNA level required for successful genotyping was $>500 \mathrm{IU} / \mathrm{ml}$.

After October 2017, genotyping was performed by RT-PCR in a Montania 4,896 device with Bosphore-HCV Genotyping V3 kit (Anatolia Diagnostic and Biotechnology Products, Turkey), and samples were scanned for genotypes 1a, 1b, 2, 3, 4, 5a, and 6. In this method, the HCV-RNA level required for successful genotyping was $>100 \mathrm{IU} / \mathrm{ml}$.

All tests were performed according to manufacturers' recommendations.

\section{Demographic Data of Patients}

Personal information and laboratory results of patients were obtained from the laboratory information system of our hospital and inspection of records in clinical files.

\section{Statistical Analysis}

Statistical analyses were performed using International Business Machines Statistical Package for the Social Sciences version 21 software. Suitability of variables to normal distribution was examined by histogram analysis and Kolmogorov-Smirnov test. For non-normally distributed variables, descriptive statistics were presented by median and interquartile ranges. For two or more intergroup comparisons, Student's t-test and Mann-Whitney $\mathrm{U}$ test were used for numerical variables, and chi-square and Fisher's exact tests were used for categorical variables. $P$ value of $<0.05$ was evaluated as statistically significant in all analyses.

\section{Results}

HCV-RNA was found to be positive in $628(26.4 \%)$ of 2,381 patients who were found as anti-HCV positive by enzyme-linked immunosorbent assay method. Median HCV viral load values of patients were calculated in log values as 5.8 (interquartile range 1.2) for 2015, 5.8 (interquartile range 1.3) for 2016, 5.8 (interquartile range 1.5) for 2017, and 5.7 (interquartile range 1.3) for 2018. The distribution of HCV-RNA results by years is shown in Table 1.

Genotyping was performed in 319 of 628 patients with HCVRNA positivity. When the retrospective records of other patients were examined, genotyping was impossible to perform because their treatment was not done at our hospital.
The mean age of 319 patients was 51.6 (standard deviation: 16.1). Female/male ratio was found as 131/188.

The most common genotypes were $1 \mathrm{~b}(61 \%), 3(19 \%)$, and $1 \mathrm{a}$ (10\%). Genotypes 1a and 3 were concomitant in two patients, genotypes $1 \mathrm{~b}$ and 3 in one patient, genotypes 2 and 3 in one patient, and genotypes 1 and 4 were concomitant in one patient.

Among all genotypes, the incidence of genotype $1 \mathrm{~b}$ was found to be $34.7 \%, 29 \%, 15.5 \%$, and 20.7\%, between 2015-2018 $(p=0.001)$, respectively. Genotype distribution by years is shown in Table 2 and in the Graphic 1.

Among 319 patients who were genotyped, 316 were evaluated in terms of nationality since nationality information was unavailable for three patients. Of these 316 patients, 238 (75.3\%) were citizens of the Republic of Turkey and 78 (24.7\%) were foreign nationals. Among foreign patients, top three nationalities were Georgian, Turkmen, and Syrian. Genotype distribution according to the nationality of patients is shown in Table 3.

Of the 238 Turkish Republic citizens who were genotyped, 168 (71\%) were found to be genotype 1b, 28 (12\%) were genotype 3 , and 25 (11\%) were genotype 1 a.

Mean age of Turkish patients with genotype $1 b$ [61.0, standard error $(S E)=12.1]$ was significantly higher compared to mean age of patients with other genotypes $(44.8, \mathrm{SE}=16.5)(p=0.001)$ (Mann-Whitney U test).

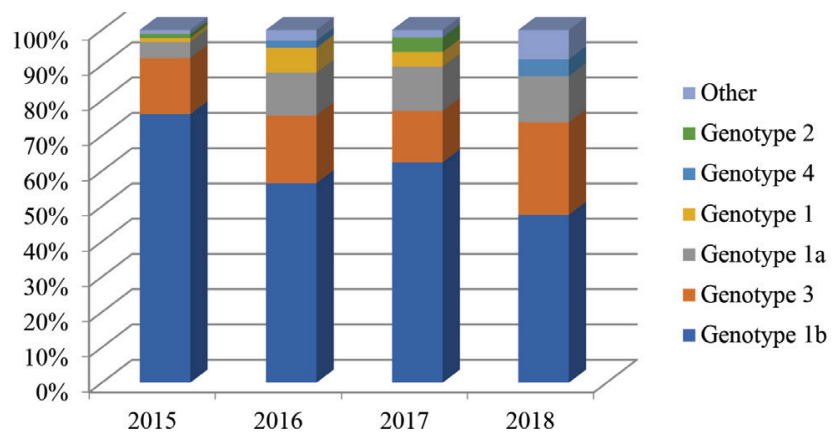

Graphic 1. Hepatitis $C$ virus genotype distribution by years

Table 1. The distribution of hepatitis $C$ virus-RNA results by years

\begin{tabular}{l|l|l|l|l|l}
\hline \multirow{2}{*}{ Year } & \multicolumn{2}{|l|}{ HCV-RNA negative } & \multicolumn{2}{l}{ HCV-RNA positive } & \multicolumn{2}{l}{ Total } \\
\cline { 2 - 6 } & $\mathbf{n}$ & $\%$ & $\mathbf{n}$ & $\%$ & $\mathbf{n}$ \\
\hline $\mathbf{2 0 1 5}$ & 432 & 69.1 & 193 & 30.9 & 625 \\
\hline $\mathbf{2 0 1 6}$ & 425 & 70.8 & 175 & 29.2 & 600 \\
\hline $\mathbf{2 0 1 7}$ & 391 & 77.4 & 114 & 22 & 505 \\
\hline $\mathbf{2 0 1 8}$ & 505 & 77.6 & 146 & 22.4 & 651 \\
\hline Total & 1,753 & 73.6 & 628 & 26.4 & 2,381 \\
\hline
\end{tabular}

HCV: Hepatitis C virus 
Mean age of Turkish patients with genotype 3 (41.0, SE=2.4) was significantly lower compared to mean age of patients with other genotypes $(58.3, \mathrm{SE}=14.6)(\mathrm{p}=0.001)$ (Mann-Whitney U test).

The prevalence of genotype $1 \mathrm{~b}$ among all genotypes was significantly higher in women (56.5\%) compared to that of men $(43.5 \%)(p=0.001)$ (Fisher's exact test).

The prevalence of genotype 3 among all genotypes was significantly lower in women (10.7\%) compared to that of men $(89.3 \%)(p=0.001)$ (Fisher's exact test).

When patient files were examined for transmission routes of $\mathrm{HCV}$, it was found that of the 80 Turkish patients, 51 patients had history of tooth extraction, 35 had history of previous operation, 17 had history of transfusion, 13 had history of transmission within household, and 11 had history of intravenous drug use. The most common genotype in these patients was found to be genotype $1 \mathrm{~b}$. The most frequent genotype detected was $3(45 \%)$ among 11 patients (14\%) who had addictions to intravenous drugs (Table 4).

\section{Discussion}

Chronic HCV infection is responsible for the majority of liverrelated mortality such as cirrhosis and hepatocellular carcinoma. Rapid recovery is observed when the treatment is applied quickly. Direct-acting antiviral drugs used in recent years provide over $90 \%$ virological response. HCV eradication is possible with new treatment options that are effective, well tolerated, and allow shorter treatment regimens ${ }^{[5]}$.

When HCV genotype distribution in the world is examined, it is seen that genotypes $1 \mathrm{a}$ and $1 \mathrm{~b}$ are most common in the USA and Europe, genotype $1 b$ is dominant in Japan, genotypes $2 a$ and $2 b$ are seen in North America, Europe, and Japan, and genotype $2 \mathrm{c}$ is seen in Northern Italy. Genotype $3 \mathrm{a}$ is common in Europe and the USA among people using intravenous drugs. Genotype 4 is common in North Africa and the Middle East, genotype 5 in South Africa, and genotype 6 is common in Hong Kong. Genotypes 7, 8, and 9 are only seen in Vietnam, whereas genotypes 10 and 11 are common in India ${ }^{[8]}$.

In the present study, the most common genotypes in all patients including both Turkish citizens and other nationalities were genotype $1 \mathrm{~b}(61 \%)$, genotype $3(19 \%)$, and genotype $1 \mathrm{a}$ $(10 \%)$. A total of $78(24.7 \%)$ genotyped patients were foreign nationals. Georgian (25 patients), Syrian (12 patients), and Turkmen (10 patients) were the top three nationalities. The most common genotype in Georgian and Turkmen nationals was genotype $1 \mathrm{~b}$, whereas genotype $1 \mathrm{a}$ was the most common in Syrian nationals. Literature studies reported genotype $1 b$ to be the most common genotype in Turkmenistan and Georgia ${ }^{[9,10]}$. As Turkey and Georgia are neighboring countries, molecular and epidemiological similarities between genotype maps of these countries are expected since travel between Georgia and Turkey has increased recently. This may also be the case with Turkmenistan.

A Syrian study reported that the most common genotype was genotype 4 followed by genotype $1^{[11]}$. In a publication in Kahramanmaraş, genotype $1(54.5 \%)$ was reported to be the most common genotype among Syrians ${ }^{[12]}$. In our present study, genotype 1a and genotype 4 were found to be equally common in Syrian citizens. In environments with increased cohabitance due to migration, molecular and epidemiological changes in genotypes may be expected.

Studies conducted in Turkey reported the most common genotype as $1 \mathrm{~b}$, but the prevalence rates vary depending on the region. The prevalence of genotype $1 b$ is reported in high ratios as 98\% in Gaziantep, 88\% in İzmir, 87.5\% in the Eastern Black Sea Region, 88.6\% in the Western Black Sea Region, $86.7 \%$ in Antakya, 84.7\% in Mersin, and 72\% in Aydın ${ }^{[13-18]}$, whereas lower rates have been reported in Antalya as \%63.3 ${ }^{[19]}$, in Adana as $58.8 \%$ and $55.2 \%$ in two separate studies ${ }^{[20,21]}$, and in Kayseri as $52.8 \%{ }^{[22]}$. In a multicenter study conducted in Turkey, the mean frequency of genotype $1 \mathrm{~b}$ was $67.7 \%$ although rates varies

Table 2. Hepatitis $\mathrm{C}$ virus genotype distribution by years

\begin{tabular}{|c|c|c|c|c|c|}
\hline \multirow{2}{*}{ Genotypes } & \multicolumn{5}{|l|}{ Year } \\
\hline & $2015(n=88)$ & $2016(n=99)$ & $2017(n=48)$ & $2018(n=84)$ & p value \\
\hline Genotype $1 b(n=193)$ & $67(34.7 \%)$ & $56(29 \%)$ & $30(15.5 \%)$ & $40(20.7 \%)$ & 0.001 \\
\hline Other genotypes $(n=126)$ & $21(16.7 \%)$ & $43(34.1 \%)$ & $18(14.3 \%)$ & $44(34.9 \%)$ & \\
\hline Genotype $3(n=62)$ & $14(22.6 \%)$ & $19(30.6 \%)$ & $7(11.3 \%)$ & $22(35.5 \%)$ & \\
\hline Genotype 1a $(n=33)$ & $4(12.1 \%)$ & $12(36.4 \%)$ & $6(18.2 \%)$ & $11(33.3 \%)$ & \\
\hline Genotype $1(n=10)$ & $1(10 \%)$ & $7(70 \%)$ & $2(20 \%)$ & 0 & \\
\hline Genotype $4(n=6)$ & 0 & $2(33.3 \%)$ & 0 & $4(66.7 \%)$ & \\
\hline Genotype $2(n=3)$ & $1(33.3 \%)$ & 0 & $2(66.7 \%)$ & 0 & \\
\hline Other genotypes* $(n=12)$ & $1(8.3 \%)$ & $3(25 \%)$ & $1(8.3 \%)$ & $7(58.3 \%)$ & \\
\hline
\end{tabular}

${ }^{*}$ Other genotypes=Genotype $3 a, 1 a / 3,1 b / 3, c-k, 2 / 3,1 / 4,3 / 4$, and 5 
by region ${ }^{[23]}$. In another study published at another hospital located on the Anatolian side of İstanbul close to our hospital, the most common genotype was reported to be $1 \mathrm{~b}$ with a rate of $56.5 \%{ }^{[24]}$. Data of our study include patients followed by one of the big hospitals located at the Anatolian side of İstanbul, and the frequency of genotype $1 \mathrm{~b}$ obtained as $61 \%$ is consistent with the data of the other hospital in İstanbul.

Other genotypes observed also vary from region to region. Second most common genotype has been reported as genotype $1 \mathrm{a}^{[16,19,20]}, 2^{[17]}$, and $4^{[22]}$ in different cities, whereas other studies reported genotype 3 as the second most common genotype ${ }^{[14,18,21]}$. Genotype 3 (19\%) was the second most common genotype in our study. In another study conducted in İstanbul, the second most common genotype was genotype 1a (22.9\%) ${ }^{[24]}$.

Geographical proximity and neighboring relations of countries or regions affect genotype distribution. It is reported that in regions of Thailand neighboring Myanmar and Vietnam, the most common genotype is genotype 6 similar to Myanmar and Vietnam, whereas in the southern regions neighboring Malaysia, the most common genotype is genotype $3 \mathrm{a}^{[25]}$. The above-mentioned data and data in the present study suggest that the geographical proximity of provinces where the study is conducted to other regions and countries, demographic characteristics of the population, socioeconomic status, and exposure to migration lead to differences in genotype distribution.

Our study has also revealed the existence of genotypes 1,2 , 4 , and others (genotypes 3a, 1a/3, 1b/3, c-k, 2/3, 1/4, 3/4, and 5). Genotypes identified by RT-PCR method and classified as "other" include $3 a, 1 a / 3,1 b / 3, c-k, 2 / 3,1 / 4,3 / 4$, and 5 . It is reported that samples with mixed type detected by RTPCR method should be verified by reference methods such as Restriction Fragment Length Polymorphism and sequence analysis ${ }^{[26]}$. It is reported that the dominant genotype responds to treatment, and mixed genotypes appear after treatment ${ }^{[27]}$. However, this present study is a retrospective study, thus, mixed genotypes were re-analyzed but could not be verified by reference methods. The limitation of this study includes the usage of two kits with different sensitivity and specificity arising from the procurement system over a four-year period and retrospectively analyzed patients with such results.

Table 3. Hepatitis $\mathrm{C}$ virus genotype distribution according to the nationality of patients

\begin{tabular}{|c|c|c|c|c|c|c|c|c|}
\hline Nationality & $\begin{array}{l}\text { Genotype } 1 \mathrm{~b} \\
\text { n (\%) }\end{array}$ & \begin{tabular}{|l} 
Genotype 3 \\
n (\%) \\
\end{tabular} & $\begin{array}{l}\text { Genotype 1a } \\
\text { n (\%) }\end{array}$ & $\begin{array}{l}\text { Genotype } 1 \\
\mathrm{n}(\%)\end{array}$ & $\begin{array}{l}\text { Genotype } 4 \\
\text { n (\%) }\end{array}$ & $\begin{array}{l}\text { Genotype } 2 \\
\text { n (\%) }\end{array}$ & $\begin{array}{l}\text { Other genotypes } \\
\mathrm{n}(\%)\end{array}$ & $\begin{array}{l}\text { Total } \\
\text { n (\%) }\end{array}$ \\
\hline Turkish & $168(71)$ & 28 (12) & 25 (11) & $8(3)$ & 1 (0) & $1(0)$ & 7 (3) & 238 \\
\hline Georgian & $12(48)$ & $11(44)$ & $1(4)$ & 0 & 0 & $1(4)$ & 0 & 25 \\
\hline Turkmen & $6(60)$ & $3(30)$ & 0 & 0 & 0 & 0 & $1(10)$ & 10 \\
\hline Syrian & 0 & $1(8)$ & $5(42)$ & 0 & $5(42)$ & 0 & $1(8)$ & 12 \\
\hline Afghanistan & $2(25)$ & $4(50)$ & 0 & 0 & 0 & $1(13)$ & $1(13)$ & 8 \\
\hline Russian & $2(40)$ & 0 & $2(40)$ & 0 & 0 & 0 & $1(20)$ & 5 \\
\hline Ukrainian & 0 & $5(100)$ & 0 & 0 & 0 & 0 & 0 & 5 \\
\hline Moldovan & $1(100)$ & 0 & 0 & 0 & 0 & 0 & 0 & 1 \\
\hline Iranian & 0 & $1(100)$ & 0 & 0 & 0 & 0 & 0 & 1 \\
\hline German & 0 & $2(67)$ & 0 & $1(33)$ & 0 & 0 & 0 & 3 \\
\hline Armenian & $1(50)$ & $1(50)$ & 0 & 0 & 0 & 0 & 0 & 2 \\
\hline Uzbek & 0 & $3(100)$ & 0 & 0 & 0 & 0 & 0 & 3 \\
\hline Azerbaijani & $1(50)$ & 0 & 0 & $1(50)$ & 0 & 0 & 0 & 2 \\
\hline Pakistani & 0 & $1(100)$ & 0 & 0 & 0 & 0 & 0 & 1 \\
\hline Total & $193(61)$ & $60(19)$ & $33(10)$ & $10(3)$ & $6(2)$ & $3(1)$ & $11(3)$ & 316 \\
\hline
\end{tabular}

Table 4. Hepatitis $\mathrm{C}$ virus genotype distribution of Turkish citizens according to the possibility of transmission routes ( $\mathrm{n}=\mathbf{8 0}$ )

\begin{tabular}{l|l|l|l|l|l|l|l}
\hline Medical history & $\begin{array}{l}\text { Genotype 1 } \\
\mathbf{n}(\%)\end{array}$ & $\begin{array}{l}\text { Genotype 1b } \\
\mathbf{n ~ ( \% )}\end{array}$ & $\begin{array}{l}\text { Genotype 1a } \\
\mathbf{n}(\%)\end{array}$ & $\begin{array}{l}\text { Genotype 2 } \\
\mathbf{n}(\%)\end{array}$ & $\begin{array}{l}\text { Genotype 2 } \\
\text { and 3 n (\%) }\end{array}$ & $\begin{array}{l}\text { Genotype 3 } \\
\mathbf{n}(\%)\end{array}$ & $\begin{array}{l}\text { Total } \\
\mathbf{n}(\%)\end{array}$ \\
\hline Tooth extraction & $3(6)$ & $41(80)$ & $4(8)$ & 0 & $1(2)$ & $2(4)$ & $51(64)$ \\
\hline Operation & $2(6)$ & $28(80)$ & $3(9)$ & $1(1)$ & 0 & $1(3)$ & $35(44)$ \\
\hline Transfusion & $1(6)$ & $13(76)$ & $2(12)$ & 0 & $1(6)$ & 0 & $17(21)$ \\
\hline Transmission within household & $1(8)$ & $6(46)$ & $2(15)$ & 0 & 0 & $4(31)$ & $13(16)$ \\
\hline Intravenous drug abuse & 0 & $3(27)$ & $3(27)$ & 0 & 0 & $5(45)$ & $11(14)$ \\
\hline
\end{tabular}


HCV prevalence in the world is higher in men due to greater exposure to risk factors such as intravenous drugs use, whereas in Turkey prevalence is higher in women, which can be explained by the fact that HCV infection in Turkey is generally nosocomial and hospitalization is more common in women compared to men ${ }^{[28]}$. A study conducted in İstanbul reported that genotype prevalence distribution varied according to age and gender. Genotypes 1 and 2 were more common in women and genotypes 3 and 4 were more common in men, whereas genotype 1 was more common in the elderly and genotype 3 in young population ${ }^{[29]}$.

In the present study, the prevalence of genotype $1 \mathrm{~b}$ was higher in women compared to men and genotype 3 was lower. The higher prevalence of $1 \mathrm{~b}$ in women may be due to greater exposure to bloodborne infection routes (the ratio of women/men with a history of transfusion, operation, and tooth extraction was 62/55). The low prevalence of genotype 3 in the present study may be attributed to the very low use of intravenous drugs in women ( 1 woman/16 men). Genotype $1 \mathrm{~b}$ is the most prevalent genotype in neighboring contries; however, HCV genotype 3 is increasing with intravenous drug abuse ${ }^{[30,31]}$. Our study shows that genotype 3 is the most prevalent genotype among patients using intravenous drug (45\%).

\section{Conclusion}

Findings of this study show that the most common genotype is $1 \mathrm{~b}$, with a prevalence that has statistically decreased over the years, whereas the prevalence of other genotypes increased. The rate of 16 was lower than that of other regions in our country. Variability in findings and difference between regions may be due to population mobility, caused by various factors such as tourism and migration. Characteristics of each province or region differ from others, thus, it will be beneficial for centers to track and keep their own data. An observation in İstanbul, one of the cities in Turkey where population mobility is intense, revealed more than half of patients with chronic hepatitis $C$ having genotype $1 \mathrm{~b}$, which means that almost one out of two patients admitted to the outpatient clinic may be infected with different genotypes, suggesting the necessity of genotyping for treatment decisions.

\section{Ethics}

Ethics Committee Approval: Approval for the study was obtained from Kartal Dr. Lütfi Kırdar Training and Research Hospital Clinical Research Ethics Committee (approval date: 12.06.2019, no: 2019/514/167/26).

Informed Consent: This study was designed retrospectively.

Peer-review: Externally peer-reviewed.

Concept: D.H., Design: D.H., A.G., R.C.S., G.S., Data Collection or Processing: D.H., A.G., A.B., Analysis or Interpretation: A.G., D.H.,
R.C.S., A.B., G.S., Literature Search: D.H., A.G., R.C.S., Writing: D.H., R.C.S., A.G.

Conflict of Interest: No conflict of interest was declared by authors.

Financial Disclosure: The authors declared that this study received no financial support.

\section{References}

1. World Health Organization. Hepatitis C: fact sheet Geneva, Switzerland. Updated date: 9 July 2019. Available from: https://www.who.int/newsroom/fact-sheets/detail/hepatitis-c

2. Choo QL, Richman KH, Han JH, Berger K, Lee C, Dong C, Gallegos C, Coit D, Medina-Selby R, Barr PJ. Genetic organization and diversity of the hepatitis C virus. Proc Natl Acad Sci U S A. 1991;88:2451-5.

3. Le Guillou-Guillemette H, Vallet S, Gaudy-Graffin C, Payan C, Pivert A, Goudeau A, Lunel-Fabiani F. Genetic diversity of the hepatitis $C$ virus: impact and issues in the antiviral therapy. World J Gastroenterol. 2007;13:2416-26.

4. Smith DB, Bukh J, Kuiken C, Muerhoff AS, Rice CM, Stapleton JT, Simmonds P. Expanded classification of hepatitis $C$ virus into 7 genotypes and 67 subtypes: updated criteria and genotype assignment web resource. Hepatology. 2014;59:318-27.

5. Zoulim F, Liang TJ, Gerbes AL, Aghemo A, Deuffic-Burban S, Dusheiko G, Fried MW, Pol S, Rockstroh JK, Terrault NA, Wiktor S. Hepatitis C virus treatment in the real world: optimising treatment and access to therapies. Gut. 2015;64:1824-33.

6. Zein NN. Clinical significance of hepatitis C virus genotypes. Clin Microbiol Rev. 2000;13:223-35.

7. Messina JP, Humphreys I, Flaxman A, Brown A, Cooke GS, Pybus OG, Barnes E. Global distribution and prevalence of hepatitis $C$ virus genotypes. Hepatology. 2015;61:77-87.

8. European Association for Study of Liver. EASL Clinical Practice Guidelines: management of hepatitis C virus infection. J Hepatol. 2014;60:392-420.

9. L'vov DK, Samokhvalov El, Mishiro $S$, Tsuda F, Selivanov NA, Okamoto $H$ Stakhanova VM, Gromashevskil VL, Aristova VA, Doroshenko NV, lashina TL, Kuzin SN, Suetina IA, Lobanov DS, Deriabin PG, Ruzaeva LA, Bezgodov VN, Frizen VI, Firsova LA, Firsova LI, Darizhapov BB, L'vov SD, Smirnov VN, Lisitsina VE, Shchukina IA: Regularities in the spread of hepatitis $C$ virus and(1) its genotypes in Russian and countries within the former USSR. Vop virusol. 1997;42:157-61.

10. Goktas S. The comparison of results in terms of HCV genotyping Turkey and Georgia patients. Proceedings of the $30^{\text {th }}$ year KLIMIK Congress; 9-12 March 2016; Antalya, Turkey. OP-10, p. 288.

11. Antaki N, Haddad M, Kebbewar K, Abdelwahab J, Hamed O, Aaraj R, Alhaj N, Haffar S, Assil M, Ftayeh M, Assaad F, Doghman D, Ali T, Nasserelddine M, Ali A, Antaki F; Syrian Working Group for the Study of Viral Hepatitis. The unexpected discovery of a focus of hepatitis $C$ virus genotype 5 in a Syrian province. Epidemiol Infect. 2009;137:79-84.

12. Kirisci Ö, Caliskan A. The Predominance of Genotype 3 in Hepatitis C Virus in the Province of Kahramanmaras, Turkey/Genotype Distribution of Syrian Refugee Patients with Hepatitis C in Kahramanmaras Province. Jundishapur J Microbiol 2019;12:e80872.

13. Harman R, Gunal O, Ozger S. Hepatitis C virus genotype distribution in patients with chronic hepatitis C in Gaziantep Province. Klimik Derg. 2017;30:68-70.

14. Uzun $B$, Sener AG, Gungor $S$, Afsar I. Distribution of Hepatitis $C$ virus genotypes in western Turkey: Experience of four years. Acta Medica Mediterr. 2014;30:1109-13. 
15. Buruk CK, Bayramoğlu G, Reis A, Kaklıkkaya N, Tosun I, Aydın F. Doğu Karadeniz Bölgesi Hepatit C Hastalarında Hepatit C Virusu Genotiplerinin Belirlenmesi [Determination of hepatitis $C$ virus genotypes among hepatitis C patients in Eastern Black Sea Region, Turkey]. Mikrobiyol Bul. 2013;47:650-7.

16. Aktas $E$, Ogedey ED, Kulah C, Comert FB. Hepatitis C virus genotypes in a province of Western Black-Sea Region, Turkey. Mikrobiyol Bul. 2010;44:64750.

17. Ozturk AB, Dogan UB, Ozturk NA, Ozyazıcı G, Demir M, Akın MS, Böngöl AS. Hepatitis $C$ virus genotypes in Adana and Antakya regions of Turkey. Turk J Med Sci. 2014;44:661-5.

18. Tezcan $\mathrm{S}$, Ulger $\mathrm{M}$, Aslan $\mathrm{G}$, Yaras $\mathrm{S}$, Altıntas E, Sezgin 0 , Emekdas G, Giray $B G$, Sungur MA. Determination of hepatitis $C$ virus genotype distribution in Mersin. Mikrobiyol Bul. 2013;47:332-8.

19. Kırdar S, Yaşa MH, Aydın N, Korkmaz GB, Öztürk ŞB, Ömürlü íK. The distribution of hepatitis $C$ virus genotypes in patients with chronic hepatitis C infection. Meandros Med Dent J. 2015;16:108-13.

20. Saglık I, Mutlu D, Ongut G, Inan D, Ogunc D, Sarınoglu RC, Baysan BÖ, Gultekin M, Colak D. Disribution of hepatitis $C$ virus genotypes among patients with chronic hepatitis $C$ infection in Akdeniz University Hospital, Antalya, Tukey: A five-year evaluation. Mikrobiyol Bul. 2014;48:429-37.

21. Cetin $A D$, Kibar $F$, Cetiner $S$, Yaman $A$. Determination of hepatitis $C$ virus genotype and HCV infection transmission routes in Cukurova University Medical Faculty Hospital. Turk Hij Den Biyol Derg. 2017;74:201-10.

22. Gokahmetoglu $\mathrm{S}$, Atalay MA, Kılınc A. Determination of the hepatitis $C$ virus genotypes with 'pyrosequencing' method. Erciyes Med J. 2011; 33:99-102.

23. Altindis $M$, Dal $T$, Akyar I, Karatuna 0 , Gokahmetoglu $S$, Ulger ST, Kulah $C$, Uzun B, Sener AG, Ozdemir M, Aydogan S, Kuskucu MA, Midilli K, Otlu B, Celen MK, Buruk K, Guducuoglu H. Six-year distribution pattern of hepatitis C virus in Turkey: A multicentre study. Biotechnol Biotec Eq. 2015;30:33540.

24. Zeytinli UO, Yücel FM, Dincer SD, Yanılmaz O, Aksaray S, Özdil K. Distribution of Hepatitis C Virus Genotypes in the Region of İstanbul Northern Anatolian Association of Public Hospitals. Viral Hepat J. 2017; 23:10-3.
25. Wasitthankasem $R$, Vongpunsawad $S$, Siripon $N$, Suya $C$, Chulothok $P$, Chaiear K, Rujirojindakul P, Kanjana S, Theamboonlers A, Tangkijvanich P, Poovorawan Y. Genotypic distribution of hepatitis $C$ virus in Thailand and Southeast Asia. PLoS One. 2015;10:e0126764.

26. Cekin Y, Gür N, Cekin AH, Altuglu I, Sertöz RY. Investigation of hepatitis C virus genotype distribution in patients with chronic hepatitis $C$ infection in Antalya Training and Research Hospital, Turkey. Mikrobiyol Bul. 2014;48:484-90.

27. Karchava $M$, Waldenström J, Parker $M$, Hallack $R$, Sharvadze L, Gatserelia L, Chkhartishvili N, Dvali N, Dzigua L, Dolmazashvili E, Norder H, Tsertsvadze T. High incidence of the hepatitis $C$ virus recombinant $2 k / 1 b$ in Georgia: Recommendations for testing and treatment. Hepatol Res. 2015;45:1292-8.

28. Bruggmann P, Berg T, Øvrehus AL, Moreno C, Brandão Mello CE, RoudotThoraval F, Marinho RT, Sherman M, Ryder SD, Sperl J, Akarca U, Balık I, Bihl F, Bilodeau M, Blasco AJ, Buti M, Calinas F, Calleja JL, Cheinquer $H$, Christensen PB, Clausen M, Coelho HS, Cornberg M, Cramp ME, Dore GJ, Doss W, Duberg AS, El-Sayed MH, Ergör G, Esmat G, Estes C, Falconer K, Félix J, Ferraz ML, Ferreira PR, Frankova S, Garcia-Samaniego J, Gerstoft J, Giria $J A$, Gonçales FL Jr, Gower E, Gschwantler M, Guimarães Pessôa $M$, Hézode C, Hofer $H$, Husa P, Idilman R, Kåberg M, Kaita KD, Kautz A, Kaymakoglu S, Krajden $M$, Krarup $H$, Laleman W, Lavanchy $D$, Lázaro P, Marotta $P$, Mauss $S$, Mendes Correa MC, Müllhaupt B, Myers RP, Negro F, Nemecek V, Örmeci N, Parkes J, Peltekian KM, Ramji A, Razavi H, Reis N, Roberts SK, Rosenberg WM, Sarmento-Castro R, Sarrazin C, Semela D, Shiha GE, Sievert W, Stärkel $P$, Stauber RE, Thompson AJ, Urbanek P, van Thiel I, Van Vlierberghe $H$, Vandijck D, Vogel W, Waked I, Wedemeyer H, Weis N, Wiegand J, Yosry A, Zekry A, Van Damme P, Aleman S, Hindman SJ. Historical epidemiology of hepatitis C virus (HCV) in selected countries. J Viral Hepat. 2014;21:5-33.

29. Karabulut N, Alacam S, Yolcu A, Onel M, Agacfidan A. Distribution of hepatitis $C$ virus genotypes in Istanbul, Turkey. Indian J Med Microbiol. 2018;36:192-6.

30. Urbánek P, Kristian P, Makara M, Hunyady B, Tomasiewicz K. Epidemiology of HCV infection in the Central European region. Clin Exp Hepatol. 2016;2:2-6.

31. Tresó B, Takács M, Dencs Á, Dudás M, Pár A, Rusvai E. Molecular epidemiology of hepatitis $C$ virus genotypes and subtypes among injecting drug users in Hungary. Euro Surveill. 2013;18:20639. 